\title{
ANALISIS KETRAMPILAN GURU MATA PELAJARAN EKONOMI DALAM PENGELOLAAN KELAS PADA PEMBELAJARAN EKONOMI DI KELAS XI IPS SMA LABORATORIUM UM
}

\author{
Nur Fadhilatul Lailiyah ${ }^{1}$, Sri Umi Mintarti Widjaja ${ }^{2}$ \\ 1. Economic Education Program, Faculty of Economics, State University Malang \\ 2. Economic Education Program, Faculty of Economics, State University Malang \\ nurfadhila222@gmail.com, sriumi.mintarti@um.ac.id
}

\begin{abstract}
Classroom management is very important since with a good class management teacher can control the teaching and leaning process even with some distractions. So the teaching and learning process can be effective and fulfill the aims that has been planed by the teacher. This study use descriptive qualitative method. The subject in this study are 11th grade economic teacher in SMA Laboratorium UM and students in 11th IPS grade. Data collection method use in this study are observation, interview, and documentation. Data analysis use in this study are data reduction, data display, conclusion and verification. The result of the study show that economic teachers' classroom management skill in 11th IPS grade on SMA Laboratorium UM is good. Teacher is already well in conditioning the class. Teacher need more communicative in creating good communication with students. In managing classroom discussions teacher need to provide games and motivation to students. But, teacher need to be more assertive in reprimand and go around the class to control student behavior.
\end{abstract}

Keywords: Classroom management, teachers'skill.

History of Article:

Received : (02 Agustus 2017), Accepted : (19 September2017), Publised: (15 October2017)

\section{Citation:}

Lailiyah, Nur Fadhilatul \& Sri Umi Mintarti (2017) Analisis Keterampilan Guru Mata Pelajaran Ekonomi Dalam Pengelolaan Kelas Pada Pembelajaran Ekonomi di Kelas XI IPS SMA Laboratorium UM [The Analysis Of Economic Lesson Skills of Teacher In Class Management In Economic Learning In Class XI IPS SMA UM Laboratory] Jurnal Pendidikan Ekonomi, 10(2), $147-156$.

(C) Universitas Negeri Malang 


\section{PENDAHULUAN}

Dalam proses pendidikan, ruang kelas menjadi salah satu tempat dimana seorang guru memberikan pelajaran kepada peserta didiknya. Tugas guru di dalam kelas sebagian besar adalah membelajarkan siswa dengan menyediakan kondisi belajar yang optimal. Kondisi belajar yang optimal dapat dicapai jika guru mampu mengatur siswa dan sarana pengajaran serta mengendalikannya dalam suasana yang menyenangkan. Sehingga, akan sangat membantu tersampainya materi yang diajarkan guru kepada peserta didik untuk mencapai tujuan pembelajaran yang sudah direncanakan. Oleh karena itu, kelas harus dikelola secara baik dan professional oleh guru.

Pengelolaan kelas merupakan ketrampilan seorang guru yang berkaitan dengan penyiapan iklim di dalam kelas yang diajarkan sehingga siswa dapat belajar secara optimal. Hal tersebut senada dengan yang dikatakan Hasibuan \& Moedjiono (2012: p.82) bahwa "Ketrampilan mengelola kelas merupakan ketrampilan guru untuk menciptakan dan memelihara kondisi belajar yang optimal dan mengembalikannya ke kondisi yang optimal apabila terjadi gangguan, baik dengan cara mendisiplinkan ataupun melakukan kegiatan remedial". Di sisi lain, pengelolaan kelas yang baik bukan hanya menonjolkan dominasi seorang pendidik di dalam kelas, namun pendidik juga mampu berinteraksi dan memberikan tindakan maupun percakapan yang membuat peserta didik aktif dalam proses belajar mengajar.

Pada saat pembelajaran berlangsung tidak luput dari permasalahan yang ditimbulkan siswa. Hal ini dilihat peneliti pada observasi, ketika guru menjelaskan materi dijumpai beberapa siswa yang kurang berkonsentrasi dan sibuk dengan kegiatannya sendiri. Pecahnya konsentrasi siswa dalam belajar dipengaruhi oleh teman yang melakukan penyimpangan, sehingga membuatnya untuk melakukan tindakan yang sama. Selain itu penyimpangan bisa timbul dari diri siswa sendiri yang kurang tertarik dengan pelajaran sehingga siswa merasa bosan dan melakukan penyimpangan. Akibatnya, tujuan pembelajaran yang sudah direncanakan guru pun sukar untuk dicapai dan pelajaran yang disampaikan tidak terserap baik pada diri peserta didik.

Menyadari hal tersebut, dalam perannya sebagai pengelola kelas, guru hendaknya mampu mengelola kelas sebagai lingkungan belajar sebagai aspek dari lingkungan sekolah yang perlu diorganisasi. Kelas selayaknya harus diatur dan diawasi agar kegiatan- kegiatan belajar terarah kepada tujuan- tujuan pendidikan. Dengan demikian guru tidak hanya memungkinkan siswa belajar, tetapi juga mengembangkan kebiasaan bekerja dan belajar secara efektif di kalangan siswa. Kuantitas dan kualitas belajar siswa di dalam kelas bergantung pada banyak faktor, salah satunya yaitu kondisi umum dan suasana di dalam kelas. Sehingga ketrampilan guru dalam pengelolaan kelas sangat penting agar pembelajaran dapat diterima baik oleh siswa dan tercapainya tujuan pembelajaran. 
Pada wawancara awal yang dilakukan peneliti dengan guru, didapatkan beberapa informasi. Bahwasanya SMA Laboratorium UM merupakan salah satu SMA swasta favorit yang memiliki banyak peningkatan dari sarana prasarana dan prestasi. Semua pengajar di SMA Laboratorium UM merupakan alumni dari UM sendiri. Selain itu SMA Laboratorium UM memiliki jumlah siswa yang banyak, sehingga akan muncul pula persoalan belajar yang lebih kompleks dan unik. Pada anak SMA yang memasuki usia remaja masalah yang paling sering dialami guru seperti anak susah diatur dan bertindak semaunya.

Dari berbagai uraian di atas, mendorong peneliti untuk melakukan penelitian yang berjudul "Analisis Ketrampilan Guru Mata Pelajaran Ekonomi dalam Pengelolaan Kelas pada Pembelajaran Ekonomi di Kelas XI IPS SMA Laboratorium UM".

\section{METODE PENELITIAN}

Pendekatan yang digunakan dalam penelitian ini adalah pendekatan deskriptif kualitatif. Tujuannya adalah untuk mengetahui bagaimana ketrampilan guru mata pelajaran ekonomi dalam pengelolaan kelas XI IPS SMA Laboratorium UM . Jenis penelitian yang digunakan dalam penelitian ini adalah jenis penelitian fenomenologi.

Kehadiran peneliti sebagai observer, pengumpul data dan pengenalisis data serta sekaligus sebagai pembuat laporan hasil penelitian. Oleh karena itu, kehadiran peneliti di lapangan mutlak diperlukan.Peneliti melakukan penelitian selama bulan Maret dan April 2017. Lokasi penelitian adalah di SMA Laboratorium Universitas Negeri Malang yang berlokasi di Jl. Bromo No. 16 Malang, Jawa Timur, Tepatnya penelitian ini dilakukan di kelas XI IPS pada mata pelajaran ekonomi.Subjek penelitian adalah guru ekonomi kelas XI IPS. Prosedur pengumpulan data yang digunakan yaitu observasi, wawancara, dan dokumentasi.

Analisis data yang dilakukan peneliti yaitu pengumpulan data, reduksi data, penyajian data, dan menarik kesimpulan serta verifikasi. Dan untuk pengecekkan keabsahan temuan peneliti menggunakan uji kredibilitas yaitu dengan meningkatkan ketekunan dan triangulasi. Serta untuk tahap-tahap penelitian dalam penelitian ini adalah tahap pendahuluan, pelaksanaan, analisis data, dan pelaporan.

\section{HASIL DAN PEMBAHASAN \\ Deskripsi Responden}

Informan dalam penelitian ini terdiri dari 7 informan yaitu guru ekonomi yang mengajar kelas XI SMA Laboratorium UM dan 6 siswa yang setiap kelas diwakilkan oleh 2 siswa.Dalam setiap kelas peneliti melakukan wawancara dengan beberapa informan yang sudah ditentukan dan telah mengikuti kegiatan pembelajaran mata pelajaran ekonomi. Pertanyaan dalam wawancara berkaitan dengan ketrampilan guru mata pelajaran ekonomi dalam pengelolaan kelas pada pembelajaran ekonomi kelas XI IPS. 


\section{Pemeliharaan Kondisi Belajar}

Memberikan Petunjuk-Petunjuk yang Jelas

Guru sudah mampu memberikan petunjuk yang jelas pada siswa. Guru menyampaikan tujuan pembelajaran sebelum memulai pelajaran. Serta kegiatan apa yang akan di lakukan pada pembelajaran ekonomi.

\section{Menghindari Kekeliruan saat Mengajar}

Guru sudah mampu menghindari kekeliruan yang mungkin timbul saat pembelajaran. Guru tepat waktu dalam memulai dan mengakhiri pelajaran. Tidak hanya itu, guru juga runtut dalam menjelaskan serta memberikan contoh yang ada di sekitar siswa sesuai dengan materi yang disampaikan. Namun, guru perlu menyederhanakan bahasa saat menjelaskan, karena dengan bahasa yang tinggi siswa akan mengalami kesulitan dalam pemahaman.

\section{Bervariasi}

Guru sudah mampu melakukan variasi media, alat dan interaksi. Guru perlu meningkatkan penggunaan variasi interaksi pada kelas XI IPS 3. Guna memberikan suasana belajar yang tidak monoton pada pelajaran ekonomi.

\section{Komunikasi Yang Baik Antara Guru Dan Siswa}

\section{Memberi Perhatian}

Dalam membagi perhatian guru mampu melihat siswa yang mengalami kesulitan walaupun siswa tersebut tidak berani untuk mengungkapkan kesulitannya. Guru mendatangi dan menanyakan apa yang menjadi kesulitan siswa yang bersangkutan. Di sisi lain jika ada individu atau kelompok yang belum paham dengan materi. Guru menjelaskan kembali materi yang belum dipahami siswa baik itu secara klasikal atau mendatangi masing- masing individu atau kelompok.

\section{Keharmonisan}

Guru ekonomi mampu menciptakan hubungan harmonis dengan siswa. Dengan menanyai kesulitan siswa begitupun siswa menyatakan apa yang menjadi kesulitannya. Sehingga timbullah timbal balik antara keduanya. Guru tetap menjaga interaksi dengan perhatian dan kehangatan yang diberikannya. Namun guru perlu lebih komunikatif dengan siswa agar siswa merasa senang dan tidak mudah bosan saat mengikuti pelajaran ekonomi.

\section{Pengelolaan Kelompok Diskusi Kelas}

\section{Memusatkan Perhatian Kelompok}

Guru sudah mampu memusatkan perhatian kelompok dengan memusatkan perhatian siswa pada suatu hal sebelum memulai pelajaran yaitu dengan memberikan gambar. Agar tidak timbul penyimpangan perhatian siswa. Kemudian guru juga sudah mampu menuntut tanggung jawab siswa pada tugas dengan 
melaporkan hasil diskusi di depan kelas. Guru juga meminta tanggapan atau pertanyaan siswa atas hasil diskusi kelompok yang sudah maju. Namun, guru perlu mengontrol setiap kegiatan siswa dalam kelompok dan memberikan game agar memberikan suasana belajar yang menyenangkan di kelas.

\section{Pendekatan Pemecahan Masalah Kelompok}

Dalam melakukan pendekatan pemecahan masalah kelompok, guru bisa membagikan handout sejumlah siswa. Selain itu guru juga memperlancar tugas tugas jika menemukan siswa yang masih kurang nilainya pada pelajaran ekonomi dengan memberi tugas tambahan. Guru sudah mampu melakukan pendekatan pemecahan masalah kelompok, namun guru perlu meningkatkan dalam pemberian motivasi pada siswa.

\section{Kontrol Terhadap Perilaku Siswa}

\section{Menunjukkan Sikap Tanggap}

Guru mampu menunjukkan sikap tanggap yang baik dengan memandang secara seksama. Selain itu, guru sudah mampu memberi reaksi pada gangguan dan ketidak acuhan siswa.Namun, sebelum memulai pelajaran guru perlu berkeliling kelas untuk melihat siswanya sudah siap dengan modul dan buku tulisnya.

\section{Menegur}

Guru perlu meningkatkan ketegasannya dalam memberikan teguran pada siswa. Diharapkan siswa tidak akan mengulangi perbuatan tersebut di lain hari. Namun, guru sudah mampu mengendalikan siswa yang ramai dengan memindah tempat duduknya dengan siswa teladan. Selain itu, guru juga menghindari teguran kasar dan menyakitkan agar siswa lebih bisa menerima nasehat yang diberikan guru.

\section{Memberi Penguatan}

Guru sudah mampu memberikan penguatan pada siswa yang bertingkah laku wajar dengan memberikan pertanyaan, motivasi dan bimbingan secara intensif. Siswa akan merasa dihargai oleh tindakan yang dilakukan guru. Sehingga siswa akan selalu mempertahankan atau bahkan meningkatkan prestasinya dan bisa menjadi contoh bagi siswa lain. Namun pada siswa yang mengganggu, setelah memberikan teguran guru perlu senantiasa mengamati perbuatan yang dilakukan siswa agar tidak mengulangi penyimpangannya kembali.

\section{Modifikasi Tingkah Laku}

Ketika guru dihadapkan dengan siswa yang terus menerus menimbulkan masalah, menanyai siswa atas kesulitannya saja tidak cukup. Namun, guru perlu tegas dalam menangani tindakan siswa yang bersangkutan. 


\section{Menemukan dan Memecahkan Tingkah Laku yang Menimbulkan Masalah}

Dalam mengatasi siswa pembuat gangguan di kelas, guru harus mengetahui apa yang menjadi penyebab gangguan siswa. Selanjutnya guru akan memberikan pemecahan terhadap gangguan yang ditimbulkan sekaligus memberikan ancaman agar siswa tidak mengulangi perbuatannya kembali.

Dari indikator kemampuan pengelolaan kelas seperti menciptakan komunikasi yang baik dengan siswa dan pengelolaan kelompok diskusi kelas sudah dilakukan dengan baik oleh guru. Namun, guru ekonomi perlu miningkatkan usahanya dalam melakukan kontrol terhadap perilaku siswa dan memelihara kondisi belajar

\section{Pembahasan}

\section{Pemeliharaan Kondisi Belajar}

Usaha guru dalam memelihara kondisi belajar di dalam kelas sudah baik. Hal ini dilakukan guru dengan memberikan petunjuk- petunjuk yang jelas berupa menyampaikan tujuan pembelajaran pada awal pembelajaran. Guru juga memberitahu siswa materi yang akan dipelajari dan kegiatan yang akan dilakukan dalam pembelajaran. Selain itu guru juga menyampaikan kegiatan yang akan dilakukan pada pertemuan selajutnya. Hal ini sesuai dengan pendapat yang dikemukakan oleh Ustman (2006 : p.99) bahwa "Guru hendaknya memberikan petunjuk yang jelas dan singkat dalam pelajaran sehingga tidak terjadi kebingungan pada diri siswa".

Upaya guru dalam menghindari kekeliruan yaitu dengan menyiapkan rencana pembelajaran (RPP). Dari RPP guru mengetahui kapan harus memulai, melakukan kegiatan inti dan menutup pelajaran. Guru juga menggunakan PPT agar materi yang disampaikan tidak keluar dari topik bahasan. Guru menyampaikan materi secara runtut untuk menghindari penyampaian yang membingungkan siswa. Ustman (2006 : P.101) berpendapat bahwa "Dalam usaha mengelola kelas secara efektif ada sejumlah kekeliruan yang harus dihindari oleh guru, yaitu sebagai berikut (1) Campur tangan yang berlebihan, (2) Kelenyapan, (3) Ketidaktepatan memulai dan mengakhiri kegiatan, (4) Penyimpangan (5) Bertele-tele, dan (6) Pengulangan penjelasan yang tidak perlu".

Setiap alat, media dan interaksi pembelajaran yang digunakan guru dalam mengajar sangatlah berpengaruh terhadap hasil belajar siswa. Guru menggunakan PPT yang ditampilkan pada LCD berupa penjelasan panjang mengenai materi. Papan tulis digunakan untuk mencatat hal - hal pokok tentang materi. Guru juga sering mengadakan diskusi kelompok pada kelas XI IPS. . Usman ( 2006 : pp.9798) mengungkapkan bahwa "Prinsip pengelolaan kelas dibagi menjadi 6 prinsip yaitu; (1) Kehangatan dan keantusiasan, (2) Tantangan, (3) Bervariasi, (4) Keluwesan, (5) Penekanan pada hal-hal positif dan (6) Penanaman disiplin diri”. 


\section{Komunikasi Baik Antara Guru dan Siswa}

Dalam menjalin komunikasi yang baik antara guru dengan peserta didik sudah baik. Hal ini ditunjukkan guru dengan memberikan perhatian yang berupa bersikap adil merata pada seluruh siswa. Guru akan menjelaskan kembali materi, apabila siswa belum paham dengan materi yang disampaikan sebelumnya. Penjelasan materi guru, dilakukan secara klasikal apabila seluruh siswa merasa kurang paham dengan materi. Namun apabila hanya beberapa individu atau kelompok yang belum paham pada materi, guru akan mendatangi dan menjelaskan pada individu atau kelompok tersebut. Sesuai dengan pendapat yang dikemukakan oleh Djamarah (dalam Wiyani, 2013: p.91) bahwa "Manajemen kelas yang efektif terjadi jika guru mampu membagi perhatiannya kepada beberapa kegiatan yang berlangsung dalam waktu yang sama. Membagi perhatian dapat dilakukan dengan dua cara: visual dan verbal".

Keharmonisan hubungan timbal balik antara guru dan siswa harus berlangsung secara baik, tanpa ada tekanan pada masing-masing pihak. Ketika ada keterbukaan antara siswa dengan guru, pelajaran akan berjalan dengan kondusif. Guru juga akan meminta siswa untuk mengoreksi pembelajaran yang telah diberikan. Dari koreksi tersebut akan menjadi acuan bagi guru untuk selalu melakukan perbaikan dalam pembelajaran ekonomi. Hal ini didukung Thomas Gordon dalam Djamarah dan Zain (2010: P.216) yang mengatakan bahwa hubungan guru dan siswa dikatakan baik apabila hubungan memiliki sifat - sifat: (1) Keterbukaan (2) Tanggap bilamana seseorang tahu bahwa dia dinilai oleh orang lain (3) Saling ketergantungan (4) Kebebasan dan (5) Saling memenuhi kebutuhan.

\section{Pengelolaan Kelompok Diskusi Kelas}

Ketrampilan guru dalam pengelolaan kelompok diskusi kelas sudah baik. Hal tersebut dilakukan guru dengan memastikan murid-murid tetap konsisten pada tugas yang diberikan. Ketika ada gangguan yang muncul guru akan menegur dan mengingatkan bahwa masing-masing siswa memiliki tugas yang harus diselesaikan. Pada kegiatan kelompok guru juga menuntut tanggung jawab siswa dengan mempresentasikan hasil diskusi kelompoknya di depan kelas. Bagi siswa yang tidak melakukan presentasi dituntut untuk memperhatikan dan memberikan tanggapan atau pertanyaan. Sebelum menyampaikan materi guru memusatkan perhatian siswa pada suatu hal untuk menghindari penyimpangan perhatian siswa.

Namun guru perlu mengontrol kegiatan siswa dalam kelompok agar kegiatan siswa bisa tetap dipertahankan ke arah positif. Selain itu guru perlu memberikan game untuk memberikan suasana belajar yang menyenangkan di kelas. Pada penelitian Febrianto (2014) mengungkapkan bahwa "Dengan keterampilan mengelola kelas dan gaya mengajar guru yang baik, akan meningkatkan keaktifan belajar siswa". 


\section{Kontrol Terhadap Perilaku Siswa}

Ketrampilan guru dalam mengontrol perilaku siswa saat kegiatan pengelolaan kelas sudah baik. Hal ini ditunjukkan guru dengan melihat kesiapan siswa sebelum memulai pelajaran. Siswa yang tidak siap untuk belajar atau tidak fokus pada pembelajaran akan ditegur dan diingatkan guru. Guru bertanya kabar murid, bertanya jika ada siswa yang tidak masuk dan meminta pendapat siswa atas materi yang telah disampaikan pada minggu sebelumnya. Siswa akan merasa dihargai dengan perhatian dan kehangatan yang diberikan guru. Dengan sikap tanggap guru mampu mengetahui perilaku positif maupun negatif dari peserta didik. Sesuai dengan pendapat yang dikemukakan oleh Ustman (2006 : p.98) "Tanggap terhadap perhatian, keterlibatan, ketidakacuhan, dan ketidakterlibatan siswa siswa dalam tugas-tugas di kelas. Kesan ketanggapan dapat ditunjukkan dengan cara memandang secara seksama, gerak mendekati, memberikan pernyataan, dan memberi reaksi terhadap gangguan dan ketakacuhan siswa".

Guru berusaha menjaga kondisi kelas tetap kondusif dengan menegur siswa yang tidak memperhatikan materi, ramai dan sibuk dengan kegiatannya sendiri. Guna menjaga agar kondisi kelas tetap kondusif dengan memberikan teguran yang jelas tertuju pada siswa yang melakukan penyimpangan terhadap kegiatan pembelajaran. Peserta didik akan belajar mengetahui kesalahan yang dilakukan dan berusaha mematuhi tata tertib yang berlaku. Hasibuan dan Moedjiono (2012 : p.83) mengungkapkan bahwa tujuan pengelolaan kelas bagi siswa "Membantu siswa untuk mengerti tingkah laku yang sesuai dengan tata tertib kelas, dan memahami bahwa teguran guru merupakan suatu peringatan, dan bukan kemarahan”.

Guru selalu berusaha memberikan penguatan pada siswa yang mengganggu agar perilakunya bisa dikendalikan. Penguatan yang diberikan berupa pemberian pertanyaan dan mengingatkan untuk diam dan fokus ke pelajaran. Guru juga memberikan penguatan pada siswa yang bertingkah laku wajar dengan memberikan pertanyaan atau reward. Hal ini akan menumbuhkan penghargaan tersendiri pada diri siswa karena sudah mengikuti pelajaran dengan baik. Sesuai dengan pendapat yang dikemukakan oleh Ustman (2006 : p.100) "Guru dapat memberikan penguatan kepada siswa yang mengganggu yaitu dengan jalan "menangkap" siswa tersebut kemudian menegurnya dan guru dapat memberikan penguatan kepada siswa yang bertingkah laku wajar dan dengan demikian menjadi contoh atau teladan tentang tingkah laku positif bagi siswa yang suka mengganggu".

Usaha guru dalam memodifikasi perilaku berfokus pada perilaku yang harus diubah. Guru berusaha menanyakan atas apa yang menjadi kesulitan siswa dan yang membuatnya tidak bisa fokus pada pembelajaran. Melalui modifikasi tingkah laku inilah guru akan membantu peserta didik untuk memecahkan masalah yang dihadapi. Supriadi dan Darmawan (2012 : p.166) mengungkapkan bahwa tujuan pengelolaan kelas bagi guru yaitu "Memberi respons secara efektif terhadap tingkah laku siswa yang menimbulkan gangguan- gangguan kecil atau ringan serta memahami dan menguasai seperangkat kemungkinan strategi yang dapat 
digunakan dalam hubungan dengan masalah tingkah laku siswa yang berlebih lebihan atau terus menerus melawan di kelas".

Ketrampilan guru dalam menemukan dan memecahkan tingkah laku perlu dilakukan untuk mengendalikan tingkah laku yang keliru dengan mengetahui penyebab dan memberikan pemecahan. Guru melakukan pendekatan untuk menganalisis penyebab masalah. Dari hasil analisis tersebut akan dijadikan acuan guru untuk menemukan pemecahannya. Guru akan melakukan kerjasama dengan wali kelas jika tidak bisa mengatasi siswa yang sering menimbulkan masalah. Sesuai dengan pendapat yang dikemukakan oleh Ustman (2006 : p.100) bahwa "Guru dapat menggunakan seperangkat cara untuk mengendalikan tingkah laku keliru yang muncul, dan ia mengetahui sebab-sebab dasar yang mengakibatkan ketidakpatutan tingkah laku tersebut serta berusaha untuk menemukan pemecahannya".

\section{KESIMPULAN}

Guru sudah baik dalam memelihara kondisi di dalam kelas. Guru menyampaikan tujuan pembelajaran yang membuat siswa paham akan maksud dan tujuan dari pembelajaran. Guru ekonomi selalu berusaha menghindari kekeliruan saat mengajar guna menciptakan kondisi kelas yang baik.

Dalam menciptakan komunikasi yang baik pada siswa, guru memberikan perhatian dan menanyakan kesulitan siswa dalam belajar. Namun, guru perlu lebih komunikatif dengan siswa agar siswa bisa lebih senang dan nyaman ketika mengikuti pembelajaran ekonomi.

Usaha guru dalam melakukan pengelolaan diskusi kelas dengan menuntut tanggung jawab pada setiap peserta didik walaupun mereka berada di kelompok. Namun, guru perlu memberikan game memberikan suasana belajar yang menyenangkan di kelas. Selain itu guru perlu meningkatkan dalam pemberian motivasi pada siswa.

Upaya guru dalam mengontrol perilaku siswa pada kegiatan pengelolaan kelas pada dasarnya sudah baik. Namun, guru perlu meningkatkan ketegasannya dalam memberikan teguran pada siswa agar penyelewengan siswa tidak terulang kembali dan guru perlu berkeliling kelas untuk melihat kesiapan siswa sebelum memulai pelajaran.

Saran yang bisa diberikan terkait dengan penelitian ini antara lain: Bagi Guru: Guru ekonomi kelas XI IPS diharapkan dapat menguasai ketrampilan mengelola kelas secara maksimal yang meliputi pemeliharaan kondisi belajar, komunikasi yang baik antara guru siswa serta pengelolaan diskusi kelasdan kontrol terhadap perilaku siswa. Ketrampilan pengelolaan kelas merupakan satu kesatuan yang mendukung satu sama lain dalam menciptakan kelas yang optimal sebagai lingkungan belajar siswa; Bagi Sekolah: Pihak sekolah untuk senantiasa tetap memperhatikan dan meningkatkan kualitas mengajar dari para guru untuk mendapatkan hasil yang lebih baik kedepannya. Komunikasi dan kerjasama pihak 
sekolah dengan para guru akan sangat berpengaruh dalam menciptakan siswa yang terdidik dan berkualitas; Bagi Peneliti Selanjutnya: Diharapkan bagi peneliti selanjutnya untuk bisa mengembangkan penelitian ini dengan menggunakan fokus yang lainnya serta bisa menjadi acuan untuk meningkatkan ketrampilan guru dalam pengelolaan kelas kedepannya.

\section{DAFTAR RUJUKAN}

Djamarah, Syaiful Bahri \& Zain, Aswan (2010) Strategi Belajar Mengajar,Cetakan 4. Jakarta: Rineka Cipta (2010) Guru dan Anak Didik Dalam Interaksi Edukatif. Jakarta : PT Rineka Cipta

Febrianto, Agung (2014) Pengaruh Keterampilan Mengelola Kelas Dan Gaya Mengajar Guru Terhadap Keaktifan Belajar Siswa Kelas XI Materi Pembelajaran Pembangunan Ekonomi SMA Negeri 2 Slawi. (Online), 2 (3) (http://journal.unnes.ac.id/artikel_sju/eeaj/3138) diakses 18 Januari 2017

Hasibuhan \& Modjiono (2012) Proses Belajar Mengajar. Bandung PT Remaja Rosda Karya

Supriadi, Didi \& Darmawan,Deni (2012) Komunikasi Pembelajaran. Bandung : PT Remaja Rosda Karya

Ustman, Moh. Uzer (2006) Menjadi Guru Profesional: Menciptakan Pembelajaran Kreatif Dan Menyenangkan. Bandung: PT Remaja Rosdakarya

Wiyani, Novan Ardy (2013) Manajemen Kelas: Teori dan Aplikasi untuk Menciptakan Kelas yang Kondusif. Jogjakarta : Ar- Russ Media. 